\title{
Detection Limits of Recombinant Secretary Proteins versus Semi-purified Protoplasmic Antigens for the Diagnosis of Spontaneous Cases of Mycobacterium avium subspecies paratuberculosis Infection in Domestic Ruminants
}

Kundan Kumar Chaubey ${ }^{1,2}$, Shoor Vir Singh ${ }^{1 *}$, Ashok Kumar Bhatia ${ }^{2}$, Rinkoo Devi Gupta ${ }^{3}$, Saurabh Gupta ${ }^{1}$, Ankur Varshney ${ }^{4}$, Manju Singh ${ }^{1}$, Manoj Kumar Singh $^{1}$, Zahra Hemati ${ }^{5}$ and Abhishek Singh Rathore ${ }^{3}$

${ }^{1}$ Animal Health Division, Central Institute for Research on Goats, Makhdoom, PO-Farah, Mathura, Uttar Pradesh, India

${ }^{2}$ Department of Microbiology and Immunology, GLA University, Chaumuhan, Mathura, Uttar Pradesh, India

${ }^{3}$ Department of Life Sciences and Biotechnology, South Asian University, New Delhi, India

${ }^{4}$ Department of Biotechnology, Mangla Yatan University, Aligarh, Uttar Pradesh, India

${ }^{5}$ Department of Pathobiology, School of Veterinary Medicine, Shiraz University, Shiraz, Iran

*Corresponding author: Shoor Vir Singh, Animal Health Division, Central Institute for Research on Goats, Makhdoom, PO-Farah, Mathura, Uttar Pradesh, India, Tel: +91565 2763260; Fax: +91 565 2763246; E-mail: shoorvir.singh@gmail.com

Received date: July 06, 2018; Accepted date: July 25, 2018; Published date: July 27, 2018

Copyright: $@ 2018$ Chaubey KK, et al. This is an open-access article distributed under the terms of the Creative Commons Attribution License, which permits unrestricted use, distribution, and reproduction in any medium, provided the original author and source are credited.

\begin{abstract}
Johne's disease is world-wide in distribution and in the absence of control programs bio-load of Mycobacterium avium subspecies paratuberculosis continues to increase in domestic livestock and their milk in the country. For the diagnosis of MAP we developed novel recombinant secretary proteins based 'cocktail ELISA' by cloning using six highly immunogenic secretary proteins. C ELISA was compared with extensively validated 'indigenous ELISA kit' using semi-purified protoplasmic antigens from novel and native strains of MAP (Indian Bison Type). A total of 1301 serum from domestic livestock (726 goats; 150 sheep; 300 cattle; 125 buffaloes) were screened to estimate the bioload of MAP. Using I ELISA bio-load of MAP was 55.3, 57.3, 58.0 and $44.0 \%$. In C ELISA it was 54.6, 56.6, 55.6 and $42.4 \%$ in goats, sheep, cattle and buffaloes respectively. Two tests were comparable in detecting MAP infection, however C ELISA had better profiling of samples and highly specific. Bio-load in C ELISA was lower, since it lacked proteins against all stages of disease. Still using fewer proteins the loss in sensitivity was not much. Therefore, results of screening of field samples with unknown status and in different stages of disease, since MAP is endemic, support the use of C ELISA as future diagnostics for MAP infection in all the domestic livestock species. As test kit $C$ ELISA will have more consistency in results due to use of expressed and purified six known proteins as compared to SPPA used in I ELISA.
\end{abstract}

Keywords: Mycobacterium avium subspecies paratuberculosis; Recombinant secretary proteins; sPPA; Cocktail ELISA; Indigenous ELISA; Domesticated ruminants

\section{Introduction}

Johne's disease (JD) caused by Mycobacterium avium subspecies paratuberculosis (MAP) is a notifiable disease and in absence of priority, bio-load of MAP continues to increase in domestic livestock and their milk in India as per our study of past 33 years [1]. MAP has widest host range, hence besides domestic livestock; MAP has been reported from wild ruminants, other animal species, primates and human beings $[2,3]$. Bio-load has also been reported from milk and milk products [1,2,4-13] and environment (soil and river water) samples [14]. In absence of control programs, bio-load of MAP sharply increased in animals $[1,15]$ in milk and milk products and in human population $[1,16]$ in India. JD seriously impedes and has negative impact on health and productivity of animals $[17,18]$. Johne's disease though list $B$ disease in OIE classifications and invites trade restrictions globally. In India, JD is endemic and responsible for high morbidity and loss in animal productivity. Though, India is highest milk producer in the world, on the basis of number of animals. However, per animal productivity is very low even in Asian countries.
Population of domestic livestock in India is highest (goats-133.0, sheep-63.0, cattle-187.0 and buffaloes-110.0 million) [19] in the world. But there is sharp upsurge in number of un-productive ruminants, primarily due to JD. Transmission of MAP continues through colostrum, milk, semen, pasture, soil and water [20-22], recently reported high bio-load of MAP in domestic livestock (42.7, 35.6, 22.5 and $40.9 \%$ in cattle, buffaloes, goats and sheep, respectively) and were $30.8 \%$ using multiple tests (microscopy, culture, PCR and I ELISA).

Control of JD was un-successful due to variable sensitivity and specificity of diagnostic tests in identifying MAP infected animals in early stages of infection [23]. MAP genome has 4350 protein-coding sequences including 3223 conserved proteins with known functions and 1088 conserved proteins with un-known functions with 39 proteins with unique identity [24]. Secretary antigens are reported to be highly immunogenic (immune-dominant) due to their presence in extracellular environment wherein likely encounter with sensitized immune cells was high. Cho et al. compared secretary antigens from supernatants and antigens of intracellular origin [25]. Secretary proteins un-like cellular proteins had greater zero-reactivity in MAP infected animals [26]. Secretary proteins are in focus for development of DIVA test and a marker vaccine. A range of new immunologically important secretary antigens of MAP have been identified using 2D- 
Citation: Chaubey KK, Singh SV, Bhatia AK, Gupta RD, Gupta S, et al. (2018) Detection Limits of Recombinant Secretary Proteins versus Semipurified Protoplasmic Antigens for the Diagnosis of Spontaneous Cases of Mycobacterium avium subspecies paratuberculosis Infection in Domestic Ruminants. J Vet Sci Technol 9: 552. doi:10.4172/2157-7579.1000552

Page 2 of 9

gel electrophoresis, chromatography, mass spectrometry and peptide mass fingerprint [27]. Currently crude antigen mix of MAP is used for immune-diagnosis. Detailed categorization of antigen framework of MAP is important to develop improved diagnostics. Cho et al. [26] identified 14 secretary proteins of MAP-JTC303 by immune-blot and mass spectrometry. Polyclonal rabbit antibodies (Rabbit anti-MAP JTC303) applied were directed against these 14 proteins but it reacted only with five secretary proteins (MAP 1693c, MAP 2168c, MAP Mod D, MAP 85c, MAP Pep A (MAP Pep AN and MAP Pep AC). MAP $1693 \mathrm{c}$ is a Peptidyl-prolyl cis-trans isomerase domain-containing secreted protein having $18.3 \mathrm{kDa}$ molecular weight (MW) conserved in MAP having unknown localization [27]. Another protein used in this study is MAP $2168 \mathrm{c}$ is a hypothetical protein expected $15.9 \mathrm{kDa} \mathrm{MW}$ protein having unknown functions and localization [25]. Mycobacterial ModD is an alanine and proline-rich secretory protein, expected 45-47 kDa MW immunogenic glycoprotein belonging to a fibronectin attachment protein (FAP) [26,27]. FAPs are a family of fibronectin-binding glycoproteins conserved in several mycobacterial species ( $M$. tuberculosis, $M$. bovis, $M$. vaccae, $M$. avium, and $M$. leprae) $[28,29]$. FAPs are important for internalization and invasion of epithelial cells by MAP, and deletion of this gene leads to enhanced aggregation in Mycobacterium smegmatis [30]. Ag 85 complex is a $30-32 \mathrm{kDa}$ family of three proteins (Ag85A, Ag85B and Ag85C) [31] each of which possesses an enzymatic mycolyl-transferase activity required for biogenesis of cord factor (trehalose-dimycolate). Proteins are encoded by three paralogous genes ( $\mathrm{fbpA}, \mathrm{fbpB}$ and $\mathrm{fbpC}$ ) located in distinct regions of bacterial genome [32]. Genes encoding three Ag 85 components from MAP have been sequenced, and at protein level, a $99 \%$ sequence identity with $M$. avium was found, with a single amino acid residue difference for each protein [33] isoleucine/threonine in position 284 of the mature Ag85C protein in MAP and M. avium, respectively. Comparisons have been made between mature protein sequences of MAP Ag 85 and M. bovis Ag 85. The 87\% of amino acid sequences of $85 \mathrm{C}$ protein were identical between MAP (MAP 3531c) and $M$. bovis [33]. MAP PepA is a serine protease and has a putative signal sequence at $\mathrm{N}$-terminus. Native PepA was significantly more antigenic in infected sheep, goats and deer [34]. PepA is conserved in Mycobacterium spp, e.g., a virulent H37Ra strain, virulent Erdman strain, H37Rv strain, and clinical isolate CSU93 with 100\% identity [26].

Serological tests have been frequently used in screening, sero-survey and diagnosis of MAP infection in domestic livestock [35]. Indigenous ELISA (I ELISA) we developed and first time made indigenous kit [36] for screening of serum and milk of 4 domestic livestock species and also for diagnosis of MAP infection in human population, since 2007 $[1,15,37,38]$. In this study, we identified six (MAP 1693c, MAP 2168c, MAP ModD, MAP 85c, MAP Pep AN, MAP Pep AC) secretary proteins from the literature [26], were cloned, expressed, purified and used to develop cocktail_ELISA (C ELISA). New C ELISA was compared with I ELISA kit; using semi purified protoplasmic antigens (sPPA) of novel MAP strain 'S5' biotype ('Indian Bison Type') of goat origin for screening of goats, sheep, cattle and buffaloes against MAP infection.

\section{Materials and Methods}

\section{History and collection of samples}

Serum samples were collected from domestic livestock (Goats, sheep, cattle and buffaloes) suspected for MAP infection.

\begin{tabular}{|c|c|c|c|c|}
\hline Sn & Livestock farms and place & $\begin{array}{l}\text { Serum } \\
\text { samples } \\
\text { (n) }\end{array}$ & $\begin{array}{l}\text { i_ELISA } \\
\text { Positives, } \\
\text { n (\%) }\end{array}$ & $\begin{array}{l}\text { C_ELISA } \\
\text { Positives, } \\
\text { n (\%) }\end{array}$ \\
\hline \multicolumn{5}{|c|}{ Goats } \\
\hline 1 & CIRG, Makhdoom, Mathura, UP & 175 & $118(67.4)$ & $116(66.2)$ \\
\hline 2 & Kurkunda village, Mathura, UP & 60 & $35(58.3)$ & $35(58.3)$ \\
\hline 3 & Kharkhari village, Gurgaon, Haryana & 174 & $72(41.3)$ & $71(40.8)$ \\
\hline 4 & Veterinary college, Mhow, MP & 171 & $95(23.3)$ & $93(54.3)$ \\
\hline 5 & SADIL, Jahangirabad, Bhopal, MP & 91 & $70(76.9)$ & $70(76.9)$ \\
\hline 6 & IGFRI, Jhansi, UP & 40 & $7(17.5)$ & $7(17.5)$ \\
\hline 7 & $\begin{array}{l}\text { Keetham village, Keetham, Agra, } \\
\text { UP }\end{array}$ & 15 & $5(33.3)$ & $5(33.3)$ \\
\hline \multicolumn{2}{|c|}{ Sub-total A } & 726 & $402(55.3)$ & $397(54.6)$ \\
\hline \multicolumn{5}{|c|}{ Sheep } \\
\hline 8 & Bhai village, Mathura, UP & 15 & $6(40.0)$ & $6(40.0)$ \\
\hline 9 & $\begin{array}{l}\text { Keetham village, Keetham, Agra, } \\
\text { UP }\end{array}$ & 15 & $5(33.3)$ & $5(33.3)$ \\
\hline 10 & SKUAST-K, Srinagar, J \& K & 40 & $7(17.5)$ & $7(17.5)$ \\
\hline 11 & IGFRI, Jhansi, UP & 40 & $28(70.0)$ & $27(67.5)$ \\
\hline 12 & LRIC, KVAFSU, Bidar, Karnataka & 40 & $40(100.0)$ & $40(100.0)$ \\
\hline \multicolumn{2}{|c|}{ Sub-total B } & 150 & $86(57.3)$ & $85(56.6)$ \\
\hline \multicolumn{5}{|c|}{ Cattle } \\
\hline 13 & Veterinary college, Mhow, MP & 171 & $81(47.3)$ & $77(45.0)$ \\
\hline 14 & Kharkhari village, Gurgaon, Haryana & 15 & $11(73.3)$ & $11(73.3)$ \\
\hline 15 & Yadu dairy farm, Alwar, Rajasthan & 19 & $17(89.4)$ & $17(89.4)$ \\
\hline 16 & Gazipur, New Delhi & 5 & $5(100.0)$ & $5(100.0)$ \\
\hline 17 & $\begin{array}{l}\text { VCRI, Namakkal, Chennai, Tamil } \\
\text { Nadu }\end{array}$ & 75 & $53(70.6)$ & $50(66.6)$ \\
\hline 19 & Harewali, Narela, New Delhi & 15 & $7(46.6)$ & $7(46.6)$ \\
\hline \multicolumn{2}{|c|}{ Sub-total C } & 300 & $174(58.0)$ & $167(55.6)$ \\
\hline \multicolumn{5}{|c|}{ Buffaloes } \\
\hline 20 & Veterinary college, Mhow, MP & 101 & $31(30.6)$ & $29(28.7)$ \\
\hline 21 & Jind, Haryana & 24 & $24(100.0)$ & $24(100.0)$ \\
\hline \multicolumn{2}{|c|}{ Sub-total D } & 125 & $55(44.0)$ & $53(42.4)$ \\
\hline
\end{tabular}

Table 1: Profile of domestic livestock species and the farms screened. n- Number; UP- Uttar Pradesh; MP- Madhya Pradesh; J \& K- Jammu and Kashmir; IGFRI- Indian Grassland and Fodder Research Institute; VCRI-Veterinary College and Research Institute; LRIC- Livestock Research and Information Center; KVAFSU- Karnataka Veterinary Animal and Fishery Sciences University; CIRG- Central Institute for Research on Goats; SADIL- State Animal Disease Investigation Laboratory. 
Citation: Chaubey KK, Singh SV, Bhatia AK, Gupta RD, Gupta S, et al. (2018) Detection Limits of Recombinant Secretary Proteins versus Semipurified Protoplasmic Antigens for the Diagnosis of Spontaneous Cases of Mycobacterium avium subspecies paratuberculosis Infection in Domestic Ruminants. J Vet Sci Technol 9: 552. doi:10.4172/2157-7579.1000552

Page 3 of 9

Since it is endemic in native livestock breeding farms and were driven from different states (Uttar Pradesh, Haryana, Madhya Pradesh, Tamil Nadu, Karnataka, Rajasthan) of the country (Table 1). Serum from 726 goats, 150 sheep, 300 cattle and 125 buffaloes were collected or received for screening against MAP and stored at $-20^{\circ} \mathrm{C}$ until used.

\section{Brief procedure of cloning, expression and purification of RSPs}

Easy cloning pJET 1.2/blunt vector (Clone-JET PCR Cloning kit, Cat. no.: \#K1231, Thermo fisher Scientific), pTZ57R/T Cloning vector (Insta clone PCR Cloning Kit, Cat. no.: \#1214, Thermo fisher Scientific, USA) and expression vector, pET-28a (+) and pET-22b (+) were used. Both expression vectors contained a T7 promoter and C-terminal 6X His-tag coding sequence of the multiple cloning regions. Six secretary proteins (MAP 1693c, MAP 2168c, MAP ModD, MAP 85c, MAP Pep AN, MAP Pep AC) were selected. Primers to six genes (MAP 1693c, MAP 2168c, MAP ModD, MAP 85c, MAP Pep AN, MAP Pep AC) of corresponding six proteins were designed (Primer Quest tool and Oligo analyzer 3.1, Integrated DNA Technology, USA) using sequences from MAP K10 (cattle type) bio-type and were amplified by designed primers from novel native MAP strain 'S5' genomic DNA. However, one gene (MAP ModD) could not be cloned in pET 28a expression vector, therefore, this gene (MAP ModD) was cloned afresh in pET 22b (+) expression vector, using primers [26]. Purification of PCR products was done using gel extraction purification kit (Gene Jet plasmid mini prep kit, Cat. No. K0502, Thermo fisher scientific, USA). Purified PCR products ligated with pJET 1.2/blunt vector or pTZ57R/T cloning vector as per protocols. Recombinant clones were transformed into competent $E$. coli XL-1/XL-10/DH5a. After sequencing the inserted ORFs, fragments were cloned into sites for directional ligation into pET-28a $(+)$ or, pET-22b (+) vectors after digestion with specific restriction enzymes. Ligation products then transformed into $E$. coli Rosetta/Bl-21 host cells for expression. Each transformed $E$. coli clone was grown in LB medium containing specific antibiotics and expression of cloned proteins were induced for 18-24 h by adding IPTG to optimized concentration range $(0.3 \mathrm{mM}$ to $1 \mathrm{mM})$. Cells were harvested by centrifugation and proteins were extracted by first disrupting cells by sonication in equilibration buffer $(50 \mathrm{mM}$, Tris. $\mathrm{HCl}, 200 \mathrm{mM} \mathrm{NaCl}, 5 \mathrm{~mm}$ DTT, $1 \mathrm{mM}$ PMSF, pH 8.0). Cellular debris was removed by centrifugation and supernatant saved. Recombinant proteins containing a C-terminal histidine tag were purified using $\mathrm{Ni}$ nitrilotriacetic acid (Ni-NTA) resin (Qiagen). Soluble proteins extracts were added to Ni-NTA resin previously washed with sonication buffer. Protein binding was occurred by gentle agitation for $4-6 \mathrm{~h}$ at $4^{\circ} \mathrm{C}$. Proteins bound to resin were purified by Gravity flow Ni-NTA column. Fractions containing recombinant antigens were pooled dialyzed against sonication buffer. Recombinant proteins were concentrated and their protein was estimated by Bradford protein estimation assay and six recombinant secretary proteins based Cocktail-ELISA was optimized.

\section{Recombinant secretary antigens (RSAs) based cocktail ELISA}

'Indirect ELISA' was developed to detect IgG antibodies against cocktail of six recombinant antigens/proteins (MAP 1693c, MAP 2168c, MAP ModD, MAP 85c, MAP Pep AN, MAP Pep AC) [39]. Flat bottom 96-well micro-titer plates (Catalogue no. 655061, Greiner bioone, made in Germany) were coated with $100 \mu$ l of cocktail of recombinant secretary proteins containing $1 \mu \mathrm{g}$ of each of 6 antigens diluted in $10 \mathrm{ml}$ antigen coating buffer. Coated plates were incubated over-night at $4^{\circ} \mathrm{C}$. After incubation, antigen-coated plates were washed one time with washing buffer (1X PBS containing $0.05 \%[\mathrm{v} / \mathrm{v}]$ Tween-20). Un-coated surfaces were then blocked (100 $\mu \mathrm{l} /$ well) with blocking buffer (PBS containing 5\% skimmed milk) for one hour at $37^{\circ} \mathrm{C}$. Following three washes with washing buffer, $100 \mu$ of diluted serum (1:50) in serum dilution buffer (0.2 gm BSA in $20 \mathrm{ml}$ of $1 \mathrm{X}$ PBS containing $0.05 \%[\mathrm{v} / \mathrm{v}]$ Tween-20) were added in duplicate to each well. Plates were incubated at $37^{\circ} \mathrm{C}$ for two hours, emptied and washed four times with washing buffer. Secondary antibodies used in this assay were peroxidase-labeled anti-species whole IgG antibody produced in rabbit at the dilution of 1:5000 for goats and sheep; 1:4000 for cattle and buffaloes in $1 \mathrm{X}$ PBS. $100 \mu \mathrm{l}$ of secondary anti-species antibody was added to each well and incubated for 50 minutes at $37^{\circ} \mathrm{C}$. After four times of washing, $100 \mu$ lof chromogenic substrate solution of O-Phenylenediamine dihydrochloride (OPD) (Cat. No. P3804, Sigma-Aldrich, Inc) prepared as per manufacturer's recommendation was added to each well. Plates were incubated for 10-15 minutes in the dark at $37^{\circ} \mathrm{C}$. Extent of the color development (Optical density) was measured at the absorbance of $450 \mathrm{~nm}$ using Bio-RAD i mark ELISA plate reader. Serum samples from culture positive and negative animals were used as positive and negative controls respectively.

Interpretation: Optical densities (OD) were transformed and expressed as sample-to-positive (S/P) ratios as per Collins (2002). OD)].

$\mathrm{S} / \mathrm{P}$ percent $=[($ Sample OD-Negative OD $) /($ Positive OD-Negative

$\mathrm{S} / \mathrm{P}$ ratios and corresponding status of recombinant cocktail secretary proteins based ELISA in animals was determined (Table 2).

\begin{tabular}{|l|l|l|}
\hline S. no & S/P Ratio & Johne's disease status \\
\hline 1 & $0.00-0.09$ & Negative (N) \\
\hline 2 & $0.10-0.24$ & Suspected or Borderline (S) \\
\hline 3 & $0.25-0.39$ & Low Positive (LP) \\
\hline 4 & $0.4-0.99$ & Positive (P) \\
\hline 5 & $1.0-10.0$ & Strong Positive (SP) \\
\hline
\end{tabular}

Table 2: $\mathrm{S} / \mathrm{P}$ ratios and status of Johne's disease, ${ }^{\star} \mathrm{LP}+\mathrm{S}+\mathrm{N}$ - Negative for MAP; SP+P- Positive for MAP.

Native antigens: For comparison semi-purified Protoplasmic antigens (sPPA) prepared from native novel biotype ('Indian Bison Type') of MAP strain 'S5' recovered from an advance case of JD in a goat were used [40]. Strain recovered from this terminally sick Jamunapari goat (extremely weak and recumbent) located at Central Institute for Research on Goats (CIRG), Makhdoom, which later succumbed to disease (JD) [5]. Protoplasmic Antigen (PPA) was harvested by whole cell sonication and lysate was centrifuged and supernatant was collected (semi-purified).

Indigenous ELISA kit: Indigenous ELISA (I ELISA) kit was initially developed for the screening of goats and sheep has since been standardized for the screening of cattle and buffaloes. Antigens (sPPA) from 'Indian Bison Type' MAP were standardized at 0.1 micro-gram $(\mu \mathrm{g})$ per well of the micro-titer plate. Serum samples were used in 1:50 dilution and anti-species horse radish peroxidase conjugate (Sigma Aldrich, USA) at the dilution of 1:5000 for goats and sheep; 1:4000 for cattle and buffaloes in 1X PBS. Serum samples from culture positive 
Citation: Chaubey KK, Singh SV, Bhatia AK, Gupta RD, Gupta S, et al. (2018) Detection Limits of Recombinant Secretary Proteins versus Semipurified Protoplasmic Antigens for the Diagnosis of Spontaneous Cases of Mycobacterium avium subspecies paratuberculosis Infection in Domestic Ruminants. J Vet Sci Technol 9: 552. doi:10.4172/2157-7579.1000552

Page 4 of 9

and negative animals and human beings were used as positive and negative controls, respectively.

S/P ratio: Optical densities (OD) were expressed as sample-topositive $(\mathrm{S} / \mathrm{P})$ ratios as per Collins (2002) by following calculations (Table 2).

\section{$S / P$ ratio value}

$=\frac{O D \text { at } 450 \mathrm{~nm} \text { of test serum }-O D \text { at } 450 \mathrm{~nm} \text { of negative control }}{O D \text { at } 450 \mathrm{n} \text { of }}$ $=\frac{O D \text { at } 450 \mathrm{~nm} \text { of positive control }-O D \text { at } 450 \mathrm{~nm} \text { of ne gative contro }}{\text { On }}$ $\mathrm{S} / \mathrm{P}$ ratio and corresponding status of JD in animals: Table 2 depicts the sample to positive ratios $(\mathrm{S} / \mathrm{P})$ and status of Johne's disease in the host.

\section{Sensitivity and Specificity:}

Sensitivity $=$ True Positive $\times 100 /$ True Positive + False Negative

Specificity $=$ True Negative $\times 100 /$ True Negative + False Positive

\section{Statistical analysis}

Mc Nemar's test and kappa agreement have applied for the measure the statistical significance between results of two tests (GraphPad software, USA).

\section{Results}

Serum ELISA in particular has been regarded as fast screening tests for 'mass screening' of large population of domestic livestock. Serum samples of 726 goats, 150 sheep, 300 cattle and 125 buffaloes were screened using two ELISA tests, Using I ELISA and C ELISA, the bio- load of MAP was 55.3, 57.3, 58.0 and 44.0\% and 54.6, 56.6, 55.6 and $42.4 \%$ in goats, sheep, cattle, buffaloes and humans, respectively (Figure 1, Table 3).
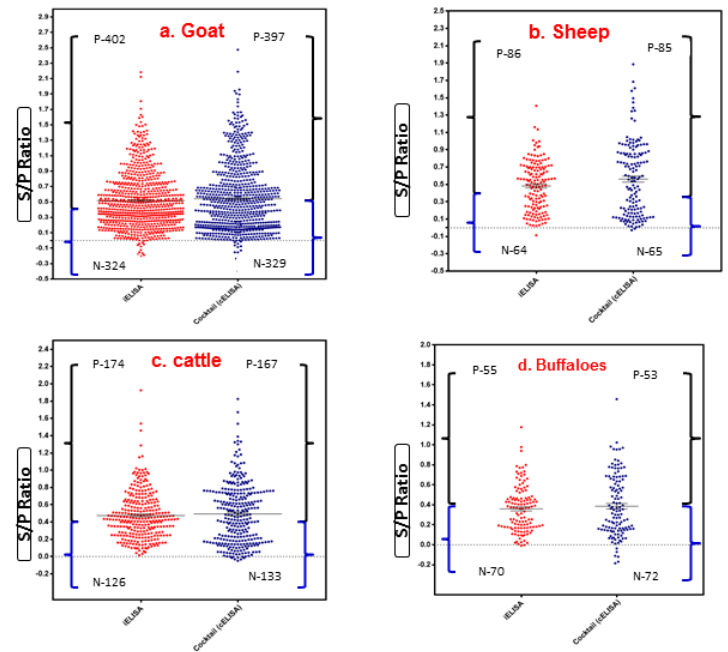

Figure 1: Scattered plot of c_ELISA showing range of correlations with i_ELISA in four domestic livestock species (Goats-726; Sheep-150; Cattle-300; Buffaloes-125).

\begin{tabular}{|l|l|l|l|l|l|l|l|l|}
\hline \multirow{2}{*}{ Species } & \multirow{2}{*}{ Tests } & \multicolumn{4}{|c|}{ Positives, $\mathbf{n}(\%)$} & \multicolumn{4}{|c|}{ Negatives, $\mathbf{n}(\%)$} \\
\cline { 3 - 9 } & $\mathbf{S P}$ & $\mathbf{P}$ & Total Pos. & LP & S & N & Total Neg. \\
\hline \multirow{2}{*}{ Goats (726) } & i_ELISA & $76(10.4)$ & $326(44.9)$ & $402(55.3)$ & $149(20.5)$ & $117(16.1)$ & $58(7.9)$ & $324(44.6)$ \\
\cline { 2 - 9 } & c_ELISA & $113(15.5)$ & $284(39.1)$ & $397(54.6)$ & $87(11.9)$ & $148(20.3)$ & $94(12.9)$ & $329(45.3)$ \\
\hline \multirow{2}{*}{ Sheep (150) } & i_ELISA & $4(2.6)$ & $82(54.6)$ & $86(57.3)$ & $22(14.6)$ & $26(17.3)$ & $16(10.6)$ & $64(42.6)$ \\
\cline { 2 - 9 } & c_ELISA & $18(12.0)$ & $67(44.6)$ & $85(56.6)$ & $11(7.3)$ & $32(21.3)$ & $22(14.6)$ & $65(43.3)$ \\
\hline \multirow{2}{*}{ Cattle (300) } & i_ELISA & $10(5.7)$ & $164(54.6)$ & $174(58.0)$ & $58(19.3)$ & $55(18.3)$ & $13(4.3)$ & $126(42.0)$ \\
\cline { 2 - 9 } & c_ELISA & $20(6.6)$ & $147(49.0)$ & $167(55.6)$ & $34(11.3)$ & $64(21.3)$ & $35(11.6)$ & $133(44.3)$ \\
\hline \multirow{2}{*}{$\begin{array}{l}\text { Buffaloes } \\
(125)\end{array}$} & i_ELISA & $1(0.8)$ & $54(43.2)$ & $55(44.0)$ & $20(16.0)$ & $37(29.6)$ & $13(10.4)$ & $70(56.0)$ \\
\cline { 2 - 9 } & c_ELISA & $2(1.6)$ & $51(40.8)$ & $53(42.4)$ & $17(13.6)$ & $35(28.0)$ & $20(16.0)$ & $72(57.6)$ \\
\hline
\end{tabular}

Table 3: Comparison of I ELISA and C ELISA values for the screening of domestic livestock and human beings against MAP infection. ${ }^{*}$ Values in parentheses are percent; LP- low positive, S-suspected, N-negative, P-positive, SP-Strong positive for MAP infection. (LP+S+N)-Negative for MAP; SP+P-Positive for MAP or infected.

Goats: Of 726 serum samples from different breeds of goats and from different places of country (Table 1) were screened by I ELISA and C ELISA abd 402 (55.3\%) and 397 (54.6\%) goats were positive and $324(44.6 \%)$ and $329(45.3 \%)$ were negative, respectively (Table 3 ). Comparison of zero-reactivity in C ELISA with I ELISA showed that results of positive and negative goats were comparable, $10(1.37 \%)$ positive samples in I ELISA were missed by C ELISA and $5(0.68 \%)$ samples positive in C ELISA were missed by I ELISA (Table 4). I ELISA was more sensitive in two tests while C ELISA is more specific than I ELISA.

\begin{tabular}{|c|c|c|c|c|c|c|c|}
\hline \multirow{2}{*}{\multicolumn{2}{|c|}{ I ELISA n (\%) }} & \multicolumn{6}{|c|}{ C ELISA, n (\%) } \\
\hline & & \multirow{2}{*}{$\begin{array}{c}\text { SP } \\
46 \\
(6.3)\end{array}$} & \multirow{2}{*}{$\begin{array}{c}\mathbf{P} \\
25(3.4)\end{array}$} & \multirow{2}{*}{$\begin{array}{c}\text { LP } \\
5(0.68)\end{array}$} & \multirow{2}{*}{ S } & \multirow{2}{*}{$\begin{array}{l}\mathbf{N} \\
-\end{array}$} & \multirow{2}{*}{$\begin{array}{c}\text { Total } \\
76 \text { (10.4 }\end{array}$} \\
\hline SP & $\begin{array}{c}76 \\
(10.4)\end{array}$ & & & & & & \\
\hline $\mathbf{P}$ & $\begin{array}{c}326 \\
(44.9)\end{array}$ & $\begin{array}{c}67 \\
(9.2)\end{array}$ & $\begin{array}{c}254 \\
(27.4)\end{array}$ & $4(0.5)$ & $1(0.1)$ & - & $\begin{array}{c}326 \\
(44.9)\end{array}$ \\
\hline LP & $\begin{array}{c}149 \\
(20.5)\end{array}$ & - & $4(0.5)$ & $\begin{array}{c}77 \\
(10.6)\end{array}$ & $63(8.6)$ & $5(0.68)$ & $\begin{array}{c}149 \\
(20.5)\end{array}$ \\
\hline
\end{tabular}


Citation: Chaubey KK, Singh SV, Bhatia AK, Gupta RD, Gupta S, et al. (2018) Detection Limits of Recombinant Secretary Proteins versus Semipurified Protoplasmic Antigens for the Diagnosis of Spontaneous Cases of Mycobacterium avium subspecies paratuberculosis Infection in Domestic Ruminants. J Vet Sci Technol 9: 552. doi:10.4172/2157-7579.1000552

Page 5 of 9

\begin{tabular}{|l|c|c|c|c|c|c|c|}
\hline S & $\begin{array}{c}\mathbf{1 1 7} \\
\mathbf{( 1 6 . 1 )}\end{array}$ & - & $1(0.1)$ & $0(0.0)$ & $77(10.6)$ & $39(5.3)$ & $\begin{array}{c}\mathbf{1 1 7} \\
\mathbf{( 1 6 . 1 )}\end{array}$ \\
\hline $\mathbf{N}$ & $\mathbf{5 8 ( 7 . 9 )}$ & - & - & - & $8(1.1)$ & $50(6.8)$ & $\mathbf{5 8 ~ ( 7 . 9 )}$ \\
\hline
\end{tabular}

Buffaloes: Serum samples of 125 buffaloes were collected from two places in two states of country. Buffaloes were screened for MAP infection by I ELISA and C ELISA and 55 (44.0\%) and 53 (42.4\%) were positive and $70(56.0)$ and $72(57.6 \%)$ were negative, respectively. Results were comparable in two ELISA tests. Two (1.6\%) positive

Table 4: Status of JD in I ELISA and C ELISA in goats. Total serum-726, LP-low positive, S-Suspected, N-Negative, P-Positive, SPStrong, positive for MAP infection.

Sheep: Of 150 serum samples of sheep collected from 5 places in three states of country (Table 1). Screening by I ELISA and C ELISA, $86(57.3 \%)$ and $85(56.6 \%)$ sheep were positive and 64 (42.6) and 65 (43.3) were negative, respectively (Table 1 ). Approximately similar results were observed in positive and negative categories. One $(0.66 \%)$ sheep positive in I ELISA was missed by C ELISA (Table 5). Like goats, here too, I ELISA was more sensitive and less specific as compared to $\mathrm{C}$ ELISA.

\begin{tabular}{|c|c|c|c|c|c|c|c|}
\hline \multirow{2}{*}{\multicolumn{2}{|c|}{ i_ELISA n (\%) }} & \multicolumn{6}{|c|}{ c_ELISA, n (\%) } \\
\hline & & \multirow{2}{*}{$\begin{array}{c}\text { SP } \\
4(2.6)\end{array}$} & \multirow{2}{*}{$\begin{array}{l}P \\
-\end{array}$} & \multirow{2}{*}{$\begin{array}{c}\text { LP } \\
-\end{array}$} & \multirow{2}{*}{$\begin{array}{l}\mathbf{S} \\
-\end{array}$} & \multirow{2}{*}{$\begin{array}{l}\mathbf{N} \\
-\end{array}$} & \multirow{2}{*}{$\begin{array}{l}\text { Total } \\
4(2.6)\end{array}$} \\
\hline SP & $4(2.6)$ & & & & & & \\
\hline $\mathbf{P}$ & $82(54.6)$ & $\begin{array}{c}14 \\
(9.3)\end{array}$ & $67(44.6)$ & $1(0.6)$ & - & - & $82(54.6)$ \\
\hline LP & $22(14.6)$ & - & - & $7(4.6)$ & $15(10.0)$ & - & $22(14.6)$ \\
\hline $\mathbf{S}$ & $26(17.3)$ & - & - & $1(0.6)$ & $14(9.3)$ & $11(7.3)$ & $26(17.3)$ \\
\hline $\mathbf{N}$ & $16(2.2)$ & - & - & $2(1.3)$ & $3(2.0)$ & $11(7.3)$ & $16(2.2)$ \\
\hline
\end{tabular}

Table 5: Status of JD in I ELISA and C ELISA in sheep. Total serum-150, LP-low positive, S-suspected, N-negative, P-positive, SPStrong positive for MAP infection.

Cattle: Cattle serum samples (300) were collected from 6 places in 5 states of country and screened by both ELISA tests (Table 1). On screening 174 (58.0) and 167 (55.6) cattle were positive and 126 $(42.0 \%)$ and $133(44.3 \%)$ were negative by I ELISA and C ELISA, respectively (Table 2). Comparable results were observed between zero-reactivity of I ELISA and C ELISA 7 (2.3\%) positive cattle in I ELISA were missed by C ELISA (Table 6). Results showed high sensitivity and less specificity of I ELISA with respect to C ELISA.

\begin{tabular}{|c|c|c|c|c|c|c|c|}
\hline \multirow{2}{*}{\multicolumn{2}{|c|}{ I ELISA, n (\%) }} & \multicolumn{6}{|c|}{ C ELISA, n (\%) } \\
\hline & & \multirow{2}{*}{$\begin{array}{l}\text { SP } \\
4(1.3)\end{array}$} & \multirow{2}{*}{$\begin{array}{c}\mathbf{P} \\
5(1.6)\end{array}$} & \multirow{2}{*}{$\begin{array}{c}\text { LP } \\
-\end{array}$} & \multirow{2}{*}{$\begin{array}{c}\mathbf{S} \\
1(0.3)\end{array}$} & \multirow{2}{*}{$\begin{array}{l}\mathbf{N} \\
-\end{array}$} & \multirow{2}{*}{$\begin{array}{c}\text { Total } \\
10(3.3)\end{array}$} \\
\hline SP & $10(3.3)$ & & & & & & \\
\hline $\mathbf{P}$ & $\begin{array}{c}164 \\
(54.6)\end{array}$ & $\begin{array}{c}16 \\
(5.3)\end{array}$ & $\begin{array}{c}142 \\
(47.3)\end{array}$ & $6(2.0)$ & - & - & $\begin{array}{c}164 \\
(54.6)\end{array}$ \\
\hline LP & $58(19.3)$ & - & - & $\begin{array}{c}25 \\
(8.3)\end{array}$ & $29(9.3)$ & $4(1.3)$ & $58(19.3)$ \\
\hline $\mathbf{s}$ & $55(18.3)$ & - & - & $3(1)$ & $32(10.6)$ & $\begin{array}{c}20 \\
(6.6)\end{array}$ & $55(18.3)$ \\
\hline $\mathbf{N}$ & $13(4.3)$ & - & - & - & $2(0.6)$ & $11(3.6)$ & $13(4.3)$ \\
\hline
\end{tabular}

Table 6: Status of JD in I ELISA and C ELISA in cattle. Total serum-300, LP-low positive, S-suspected, N-negative, P-positive, SPStrong positive for MAP infection.

buffaloes in I ELISA were missed by C ELISA (Table 7). Results showed comparatively high specificity and less sensitivity of C ELISA than I ELISA in buffaloes also.

\begin{tabular}{|c|c|c|c|c|c|c|c|}
\hline \multirow{2}{*}{ i_ELISA, $\mathbf{n}(\%)$} & \multicolumn{7}{|c|}{ C_ELISA, $\mathbf{n}(\%)$} \\
\cline { 3 - 8 } & SP & P & LP & S & N & Total \\
\hline SP & $\mathbf{1}(\mathbf{0 . 8 )}$ & $1(0.8)$ & - & - & - & - & $\mathbf{1}(\mathbf{0 . 8 )}$ \\
\hline P & $\mathbf{5 4}(\mathbf{4 3 . 2 )}$ & $1(0.8)$ & $50(40.0)$ & $3(2.4)$ & - & - & $\mathbf{5 4}(\mathbf{4 3 . 2 )}$ \\
\hline LP & $\mathbf{2 0 ( 1 6 . 0 )}$ & - & - & $13(10.4)$ & $6(4.8)$ & $1(0.8)$ & $\mathbf{2 0}(\mathbf{1 6 . 0 )}$ \\
\hline S & $\mathbf{3 7 ( 2 9 . 6 )}$ & - & - & $2(1.6)$ & $26(20.8)$ & $9(7.2)$ & $\mathbf{3 7}(\mathbf{2 9 . 6 )}$ \\
\hline N & $\mathbf{1 3 ( 1 0 . 4 )}$ & - & - & - & $3(2.4)$ & 10 & $\mathbf{1 3 ( 1 0 . 4 )}$ \\
\hline
\end{tabular}

Table 7: Status of JD in i_ELISA and c_ELISA in buffaloes. Total serum-125, LP-low positive, S-suspected, N-negative, P-positive, SPStrong positive for MAP infection.

In Table 8, the results of I ELISA and C ELISA have been compared. Of 726 goats, 150 sheep, 300 cattle and 125 buffaloes screened $54.6 \%$ (397) goats, $56.6 \%$ (85) sheep, 55.6\% (167) cattle, $42.0 \%$ (53) buffaloes and $44.6 \%$ (324) goats, $43.3 \%$ (65) sheep, $48.6 \%$ (146) cattle and $54.7 \%$ (69) buffaloes were positive and negative in both the tests. A small number of $0.68 \%$ (5) goats, 0.66 (1) sheep, 2.33 (7) cattle and 2.4\% (3) buffaloes positive in I ELISA were missed in C ELISA test.

\begin{tabular}{|l|l|l|l|l|}
\hline \multirow{2}{*}{ Tests } & \multicolumn{4}{|c|}{ Combinations, $\mathbf{n}(\%)$} \\
\cline { 2 - 5 } & $\mathbf{1}$ & $\mathbf{2}$ & $\mathbf{3}$ & $\mathbf{4}$ \\
\hline I ELISA & + & - & + & - \\
\hline C ELISA & + & - & - & + \\
\hline Goat (726) & $397(54.6)$ & $324(44.6)$ & $5(0.68)$ & $0(0.0)$ \\
\hline Sheep (150) & $85(56.6)$ & $65(43.3)$ & $1(0.66)$ & $0(0.0)$ \\
\hline Cattle (300) & $167(55.6)$ & $146(48.6)$ & $7(2.33)$ & $0(0.0)$ \\
\hline Buffaloes (125) & $53(42.0)$ & $69(54.7)$ & $3(2.4)$ & $0(0.0)$ \\
\hline
\end{tabular}

Table 8: Comparative results of I ELISA and C ELISA in four domestic livestock species (Goats, sheep, cattle and buffaloes), ${ }^{*}$ Value in parenthesis are per cent.

\section{Sensitivity and specificity of C ELISA in domestic ruminants}

a. Comparison of I ELISA with C ELISA: Sensitivity of I ELISA was $100.0 \%$ in all four domestic livestock species (goats, sheep, cattle, buffaloes). Specificity was $98.5,98.5,98.5$ and $95.8 \%$ in goats, sheep, cattle, and buffaloes, respectively (Table 9).

b. Comparison of C ELISA with I ELISA: Sensitivity of C ELISA was 98.7, 98.8, 95.9 and $94.6 \%$ in goats, sheep, cattle, buffaloes, respectively and specificity was $100.0 \%$ in all four domesticated species (Table 9). 
Citation: Chaubey KK, Singh SV, Bhatia AK, Gupta RD, Gupta S, et al. (2018) Detection Limits of Recombinant Secretary Proteins versus Semipurified Protoplasmic Antigens for the Diagnosis of Spontaneous Cases of Mycobacterium avium subspecies paratuberculosis Infection in Domestic Ruminants. J Vet Sci Technol 9: 552. doi:10.4172/2157-7579.1000552

Page 6 of 9

\begin{tabular}{|l|l|l|l|l|l|l|}
\hline Species & Test & TP & TN & FP & FN & Sen and Sp \% \\
\hline \multirow{2}{*}{ Goats (726) } & i_ELISA & 397 & 324 & 5 & 0 & 100.0 and 98.5 \\
\cline { 2 - 7 } & C_ELISA & 397 & 324 & 0 & 5 & 98.7 and 100.0 \\
\hline \multirow{2}{*}{ Sheep (150) } & i_ELISA & 85 & 65 & 1 & 0 & 100 and 98.5 \\
\cline { 2 - 7 } & C_ELISA & 85 & 65 & 0 & 1 & 98.8 and 100.0 \\
\hline \multirow{2}{*}{ Cattle (300) } & i_ELISA & 167 & 146 & 7 & 0 & 100.0 and 98.5 \\
\cline { 2 - 7 } & C_ELISA & 167 & 146 & 0 & 7 & 95.9 and 100.0 \\
\hline \multirow{2}{*}{$\begin{array}{c}\text { Buffaloes } \\
(125)\end{array}$} & i_ELISA & 53 & 69 & 3 & 0 & 100.0 and 95.8 \\
\cline { 2 - 7 } & C_ELISA & 53 & 69 & 0 & 3 & 94.6 and 100.0 \\
\hline
\end{tabular}

c_ELISA with i_ELISA as standard test, TP- true positive; FP-false positive; TN- true negative; FN- false negative; Sen- sensitivity; Spspecificity.

\section{Statistical analysis}

Using Mc-Nemar test and kappa agreement, $\mathrm{P}$ value and kappa agreement were calculated. $\mathrm{P}$ values were $0.0736,1.000,0.0233$ and 0.2482 and Kappa agreements are $0.986,0.987,0.956$ and 0.951 in goats, sheep, cattle and buffaloes, respectively. Strength of agreement was perfect in all the four domestic livestock species, respectively (Table 10).

Table 9: Sensitivity and specificity of two types of antigens (Cocktail of recombinant secretary proteins and semi-purified protoplasmic) in

\begin{tabular}{|l|l|l|l|l|l|l|}
\hline \multirow{2}{*}{ S. no } & \multirow{2}{*}{ Species } & P value & Kappa & \multicolumn{2}{|l|}{$\begin{array}{l}\text { Strength } \\
\text { agreement }\end{array}$} & of \\
\cline { 3 - 7 } & Status & Value & \multicolumn{2}{|l|}{ 95\% Confidence interval } \\
\hline 1 & Goats & Not quite significantly different & 0.0736 & $0.986 \pm 0.006$ & Perfect & 0.974 to 0.998 \\
\hline 2 & Sheep & Difference is not significant & 1.000 & $0.987 \pm 0.013$ & Perfect & 0.960 to 1.000 \\
\hline 3 & Cattle & Significantly different & 0.0233 & $0.956 \pm 0.016$ & Perfect & 0.924 to 0.988 \\
\hline 4 & Buffaloes & Difference is not significant & 0.2482 & $0.951 \pm 0.028$ & Perfect & 0.897 to 1.000 \\
\hline
\end{tabular}

Table 10: P value (Mc-Nemar test) and Kappa agreement between I ELISA and C ELISA in goats, sheep, cattle, buffaloes,

\section{Discussion}

Control and eradication of MAP infection in domestic livestock is essential to prevent transmission to human population through food (milk) chain. Accurate and timely diagnostic is pre-requisite to achieve above goals. Therefore specificity of assay is crucial for screening of MAP infection in early stages of infection in domestic livestock species. In this study two 'indigenously developed ELISA' assays (I ELISA and C ELISA) were used for screening of goats, sheep, cattle and buffaloes. Johne's disease is a major health concern in domestic and wild animals as well as in human population $[1,2,41]$. Currently there is no test that can precisely diagnose all cases with $100 \%$ accuracy $[14,42]$, therefore, we evaluated C ELISA with earlier developed and highly validated 'I ELISA' for better profiling of results and with view to improve the sensitivity and specificity of newly developed C ELISA assay.

'I ELISA kit' has been standardized for four domestic ruminant species $[43,44]$. Large number of studies compared the sensitivity and specificity of different ELISA assays for screening of MAP and to diagnose MAP infection in cattle and sheep. However studies are limited in goats and buffaloes being Asian animals. MAP is major threat for the health and productivity of domestic livestock. Country possessing highest population of buffaloes, goats (In India), cattle $\left(\mathrm{I}^{\text {st }}\right)$, sheep (III ${ }^{\text {rd }}$ ) and leading milk producer in the world. But per animal productivity it is very low, even behind Egypt, Iran and Pakistan in Asian countries. This is mainly due to the fact that livestock population of the country is endemic for MAP infection $[1,14]$. In absence of control programs and focus, MAP infection continues to increase at fast rate in the domestic livestock population. Using semi-purified protoplasmic antigen (sPPA) of goat origin harvested from 'Indian Bison type' biotype of MAP (strain 'S5') based 'I ELISA' showed significantly higher sensitivity as compared to commercially available ELISA kits $[40,43,45]$. I ELISA correlated well with culture and was good screening test for domestic livestock [40]. In another study, sensitivity and specificity of I ELISA kit was 66.6, 75.0\% and 68.1, 66.6\% with tissue culture and PCR respectively [46]. Similar comparative studies showed that I ELISA had superior diagnostic potential exhibiting high sensitivity as compared to commercial ELISA kits [43]. Kumar et al. examined sensitivity of fecal microscopy with fecal culture and serum I ELISA and was 90.0 and $65.0 \%$ respectively and agreement was substantial with both tests [17]. Other studies also reported that I ELISA kit had improved detection rate of MAP in test samples $[15,42,46]$ Using multiple tests including I ELISA, showed considerable rise in bio-load of MAP from $28.9 \%$ to $47.0 \%$ by Singh et al. While Yadav et al. used I ELISA for the screening of slaughtered buffaloes, none and $46.7 \%$ animals were positive using purified protoplasmic antigen (PPA) of bovine origin (Allied Monitor Inc., USA) and sPPA of native strain (S5) biotype as 'Indian Bison Type' for MAP antibodies, respectively [47]. This study showed buffaloes being Asian domestic livestock species exhibited very low sensitivity. Kumar et al. indicated greater sensitivity of species specific antigens [46]. Chaubey et al. reported I ELISA (Indigenous G-ELISA) with respect to commercial antigen based B ELISA and commercial sr-ELISA had 100.0 and $100.0 \%$ sensitivity and 44.4 and $11.4 \%$ specificity, respectively. Pahangchopi et al. evaluated I ELISA used antigens from native MAP strain (S5), was superior over AGPT using commercial antigen (ATCC 19698, UK used for making Johnin) in India [48]. Chaubey et al. compared sensitivity and specificity of EV ELISA with I ELISA, EV ELISA was less sensitive than I ELISA [22]. These studies 
Citation: Chaubey KK, Singh SV, Bhatia AK, Gupta RD, Gupta S, et al. (2018) Detection Limits of Recombinant Secretary Proteins versus Semipurified Protoplasmic Antigens for the Diagnosis of Spontaneous Cases of Mycobacterium avium subspecies paratuberculosis Infection in Domestic Ruminants. J Vet Sci Technol 9: 552. doi:10.4172/2157-7579.1000552

Page 7 of 9

showed major problem of lowered sensitivity of antigens used in commercial ELISA kits using different bio-type used as antigen source. Antigen source and purification were major factors crucial for sensitivity and specificity in ELISA kits.

Secreted proteins have been acknowledged to play central roles in bacterial-host interactions. Secreted proteins present in culture filtrate of MAP, have been focus of this study since considered to be immunedominant and involved in inducing protective immunity [49]. MAP specific secretary antigens can serve as markers for early diagnosis of JD. Comparing secretary proteins with other cellular proteins showed greater sero-reactivity in MAP infected animals. Secretary proteins are also focus in DIVA based diagnostics and vaccine development. Range of new immunologically important secretary antigens have been identified in MAP using 2D-gel electrophoresis, chromatography, mass spectrometry and peptide mass finger printing. Secretary antigens have major impact on development of novel sero-diagnostic techniques with improved sensitivity and specificity [50-53].

Cho et al. examined serum from infected cattle for immune-blotting which showed infected serum samples reacted strongly with secretary antigens as compared to antigens of intracellular origin [27]. Sensitivity of sero-diagnostic test improved with use of MAP culture filtrate (CF)/secretory proteins and similarly in case of other Mycobacterial pathogens, including $M$. bovis and M. tuberculosis [46,54-56]. Use of MAP CF antigens in ELISAs increased assay sensitivity by $25 \%$ over commercial ELISA's for low MAP shedding animals [57]. Recently, early zero-diagnosis was addressed using experimentally infected calves and screening for antibody responses to a panel of 96 recombinant MAP antigens [58]. Antibody responses were detected as early as 70 days post-infection. However, fluctuations in antibody responses and epitope specificity were observed over 321 days [59]. Similar results were found in our earlier studies [59], where in peak titers were achieved at 60 days after vaccination of goats. The variability in achieving peak titer varied as per the damage to the lymphoid system (mesenteric lymph nodes, Peyer's patches) in the infected animals [59]. In Indian conditions, animals in all the four livestock species are endemic for MAP infection [16], therefore normal condition of animals (physical and internal, especially lymphoid tissues) is very poor, which leads to slower response to MAP infection. Many times animals escape the cut off S/P ratio due to poor antibody response. Therefore in Indian conditions, where MAP infection is endemic and condition of domestic livestock is poor due to low grade and in-sufficient nutrition, production and environmental stress etc., the cut-off for positive S/P ratio in ELISA assays (I ELISA and C ELISA) should be dynamic and decided herd to herd and animal to animal. However, it may not be practical, therefore current focus is to first get rid of super-shedders or animals in high cut-off range (Positives and strong positives in $\mathrm{S} / \mathrm{P}$ ratio) and in second and third stages these cut-offs can be lowered to include low positives as positives. If we include at this stage, the number of animals positive will be too high to manage.

Some studies suggested that secreted proteins may be better as solid-phase ELISA antigens resulting in a more sensitive assay $[25,60]$. Pradenas et al. reported that most CF proteins have low molecular weight and reacted strongly with sera from culture-positive cases of JD [61]. They observed a high degree of difference in CF protein immunereactivity in MAP infected animals. Serum samples from cattle with clinical JD or heavy fecal shedders of bacilli reacted more intensively to CF proteins. Infected goats and sheep serum samples showed reactivity with CF proteins tested in immune-blots. These results suggested that a cocktail of CF proteins of MAP could be good candidates as antigens for zero-diagnosis. JD. Dheenadhayalan et al. [36] also reported immunogenicity of five recombinant antigens, namely MAP 2411, ClpP (MAP 2281c), Ppa (MAP 0435 c), 990 MAP 0593 c and Gre A (MAP $1027 \mathrm{c}$ ). These recombinant antigens were tested with serum samples from 41 sheep with known MAP infection and 41 noninfected control sheep. Two of these antigens, MAP $0593 \mathrm{c}$ and ClpP, reacted against $58.5 \%$ and $46.3 \%$ test positive sera and $12.1 \%$ and $4.9 \%$ of the 995 negative control sera, respectively. An earlier study 1000 tested recombinant antigens of Ag85A, Ag85B, Ag85C and SOD in ELISA with sera from 60 MAP shedding cows and 22 non-shedding cows [15]. Antigens of the Ag85 complex and SOD showed high reactivity against sera from the MAP shedding cows and little reactivity against sera from the non-shedding cows. Otherwise also commercial production of ELISA kits using recombinant proteins will have more uniform results as compared to ELISA kits developed from MAP strain in continuous passage (Strain S5 of MAP, Indian Bison Type) and may not show uniform results and may vary from batch to batch, which is not desirable in commercial kits.

\section{Conclusion}

Increased knowledge of the comparative accuracy of two ELISA based diagnostic assay may help to choose appropriate assay for the screening and control of MAP infection in the domestic livestock population of the country. Study demonstrated differences in the performance of the currently available diagnostic tests for $M A P$ infection in goats, sheep, cattle and buffaloes. Indigenous ELISA was low-cost and easy to develop in laboratory had higher sensitivity in early infection of MAP and was good for screening test for four domestic livestock species. However, recombinant secretory proteins based cocktail ELISA showed better profiling of results with improved sensitivity and high specificity. So, cocktail of secretary proteins based C ELISA can be used as future diagnostics for MAP infection in domestic livestock species in India.

\section{Ethical Approval}

Central Institute for Research on Goats, Makhdoom, Mathura ethical committee chaired by Member Secretary, Institutional Animal Ethics committee (IAEC) and The Committee for the Purpose of Control and Supervision of Experiments on Animals (CPCSEA), New Delhi has approved works were performed under Indian Council of Medical Research Project [grant number 5/8/5/28/TF/2013/ECD-I], ICMR, New Delhi, India under reference number IAEC/CIRG/16-17 dated 12.05.2016 and confirmed that this project do not have any ethical issue. Serum samples were collected/ received only for laboratory analysis. We have avoided unnecessary pain and suffering of the animals. Samples were not collected from endangered or protected species.

\section{Acknowledgement}

The authors are thankful to the Director, CIRG, Makhdoom, Mathura for providing necessary facilities. We are also thankful to ICMR Project, ICMR, New Delhi for providing funds for this work. All the animal samples (serums) screened in this study were brought under Indian Council of Medical Research Project and approved by the project approval committee. 
Citation: Chaubey KK, Singh SV, Bhatia AK, Gupta RD, Gupta S, et al. (2018) Detection Limits of Recombinant Secretary Proteins versus Semipurified Protoplasmic Antigens for the Diagnosis of Spontaneous Cases of Mycobacterium avium subspecies paratuberculosis Infection in Domestic Ruminants. J Vet Sci Technol 9: 552. doi:10.4172/2157-7579.1000552

Page 8 of 9

\section{References}

1. Chaubey KK, Singh SV, Gupta S, Singh M, Sohal JS, et al. (2017) Mycobacterium avium subspecies para-tuberculosis-an important food borne pathogen of high public health significance with special reference to India: an update. Vet Q 36: 203-227.

2. Chaubey KK, Gupta RD, Gupta S, Singh SV, Bhatia AK, et al. (2016) Trends and advances in the diagnosis and control of paratuberculosis in domestic livestock. Vet Q 36: 203-227.

3. Singh AV, Singh SV, Makharia GK, Singh PK, Sohal JS (2008) Presence and characterization of Mycobacterium avium subspecies paratuberculosis from clinical and suspected cases of Crohn's disease and in the healthy human population in India. Int J Infect Dis 12: 190-197.

4. Singh SV, Vihan VS (2004) Detection of Mycobacterium avium subspecies paratuberculosis goat milk. Small Rumin Res 54: 231-235.

5. Singh SV, Singh AV, Singh R, Sandhu KS, Singh PK, et al. (2007) Evaluation of highly sensitive indigenous milk ELISA kit with fecal culture, milk culture and fecal-PCR for the diagnosis of bovine Johne's disease (BJD) in India. Comp Immunol Microbiol Infect Dis 30: 175-186.

6. Singh SV, Stephen BJ, Singh M, Gupta S, Chaubey KK, et al. (2016) Evaluation of new 'indigenous milk dot-ELISA' as 'Field Test' vis-à-vis milk plate-ELISA for the detection of Mycobacterium avium subspecies paratuberculosis infection in lactating domestic livestock. Indian J Biotechnol 15: 166-171.

7. Singh M, Singh SV, Gupta S, Chaubey KK, Sohal JS, et al. (2018) Bioincidence of Mycobacterium avium subspecies paratuberculosis in the pasteurized liquid milk, flavoured milk and milk powder commercially sold by leading market brands in India. J Exp Biol Agric Sci 6: 188-203.

8. Sharma G, Singh SV, Sevilla I, Singh AV, Whittington RJ, et al. (2008) Evaluation of indigenous milk ELISA with m-culture and m-PCR for the diagnosis of Bovine Johne's disease (BJD) in lactating Indian dairy cattle. Res Vet Sci 84: 30-37.

9. Kumar S, Singh SV, Sevilla I, Singh AV, Whittington RJ, et al. (2008) Lacto-prevalence, genotyping of Mycobacterium avium subspecies paratuberculosis and evaluation of three diagnostic tests in milk of naturally infected goatherds. Small Rumin Res 74: 37-44.

10. Shankar H, Singh SV, Singh PK, Singh AV, Sohal JS, et al. (2008) Presence, characterization and genotype profiles of Mycobacterium avium subspecies paratuberculosis from un-pasteurized individual and pooled milk, commercial pasteurized milk, and milk products in India by culture, PCR and PCR-REA methods. Int J Infect Dis 14: e121-126.

11. Shankar H, Singh SV, Singh PK, Singh AV, Sohal JS, et al. (2010). Presence, characterization, and genotype profiles of Mycobacterium avium subspecies paratuberculosis from unpasteurized individual and pooled milk, commercial pasteurized milk, and milk products in India by culture, PCR, and PCR-REA methods. International Journal of Infectious Diseases 14: e121-126.

12. Raghuvanshi TS, Sharma RB, Singh AV, Singh B, Singh SV, et al. (2010) 'Indigenous milk ELISA kit' vis a vis multiple test regime for the estimation of lacto-prevalence of Mycobacterium avium subspecies paratuberculosis in goat herds endemic for Johne's disease. Indian J Comp Microbiol, Immunol Infect Dis 31: 41-43.

13. Raghuvanshi T, Singh SV, Sharma RB, Gupta S, Chaubey KK, et al. (2013) Identification of Mycobacterium Avium subspecies paratuberculosis in fresh cheese (paneer) from goat herds endemic for Johne's disease. J Infect Mol Biol 1: 46-48.

14. Singh SV, Tiwari A, Singh AV, Singh PK, Singh B, et al. (2012) Contamination of natural resources (soil and river water) with Mycobacterium avium subspecies paratuberculosis in three districts of Uttar Pradesh: a pilot study. Haryana Vet 51: 1-5.

15. Singh SV, Singh PK, Singh AV, Sohal JS, Kumar N, et al. (2014) Bio-load and bio-type profiles of Mycobacterium avium subspecies paratuberculosis infection in the domestic livestock population endemic for Johne's disease: a survey of 28 years (1985-2013) in India. Transbound Emerg Dis 61: 43-55.
16. Singh SV, Kumar N, Sohal JS, Singh AV, Singh PK, et al. (2014) First mass screening of the human population to estimate the bio-load of Mycobacterium avium subspecies paratuberculosis in North India. J Biol Sci 14: 237-247.

17. Rawat KD, Chaudhary S, Kumar N, Gupta S, Chaubey KK, et al. (2014) Economic losses in a commercial dairy farm due to the outbreak of Johne's disease in India. Res J Vet Pract 2: 73.

18. Vinodhkumar OR, Gunaseelan L, Ronald BS, Sakthivalan SM (2013) Slaughterhouse prevalence of ovine paratuberculosis in southern India. Trop Anim Health Prod 45: 1063-1069.

19. FAO (FAOSTAT) (2014) Food and Agriculture Organization, Rome.

20. Singh SV, Kumar N, Singh SN, Bhattacharya T, Sohal JS, et al. (2013) Genome Sequence of the "Indian Bison Type" Biotype of Mycobacterium avium subsp. paratuberculosis Strain S5. J Bacteriol: Genome Announcements. 1, e00005-13.

21. Lambeth C, Reddacliff LA, Windsor P, Abbott KA, McGregor H, et al. (2004) Intrauterine and transmammary transmission of Mycobacterium avium subsp paratuberculosis in sheep. Aust Vet J 82: 504-508.

22. Lisby G, Andersen J, Engbaek K, Binder V (1994) Mycobacterium paratuberculosis in Intestinal Tissue from Patients with Crohn's Disease Demonstrated by a Nested Primer Polymerase Chain Reaction. Scand J Gastroenterol 29: 923-929.

23. Stinear TP, Seemann T, Harrison PF, Jenkin GA, Davies JK, et al. (2008) Insights from the complete genome sequence of Mycobacterium marinum on the evolution of Mycobacterium tuberculosis. Genome res 18: 729-741.

24. Cho D, Collins MT (2006) Comparison of the proteosomes and antigenicities of secreted and cellular proteins produced by mycobacterium para-tuberculosis. Clin Vaccine Immunol 13: 1155-1161.

25. Cho D, Shin SJ, Talaat AM, Collins MT (2007) Cloning, expression, purification and sero-diagnostic evaluation of fourteen Mycobacterium para-tuberculosis proteins. Protein Expr Purif 53: 411-420.

26. Cho D, Sung N, Collins MT (2006) Identification of proteins of potential diagnostic value for bovine para-tuberculosis. Proteomics 6: 5785-5794.

27. Mon ML, Viale M, Baschetti G, Pinedo FA, Gioffre A, et al. (2012) Search for Mycobacterium avium Subspecies paratuberculosis Antigens for the Diagnosis of paratuberculosis. Vet Med Int: 1-9.

28. Ratliff TJ, McCarthy R, Telle WB, Brown EJ (1993) Purification of a mycobacterial adhesin for fibronectin. Infect Immun 61: 1889-1894.

29. Laqueyrerie A, Militzer P, Romain F, Eiglmeier K, Cole S, et al. (1995) Cloning, sequencing, and expression of the apa gene coding for the Mycobacterium tuberculosis 45/47- kilodalton secreted antigen complex. Infect Immun 63: 4003-4010.

30. Shorey JS, Holsti MA, Ratliff TL, Allen PM, Brown EJ (1996) Characterization of the fibronectin-attachment protein of Mycobacterium avium reveals a fibronectin-binding motif conserved among mycobacteria. Mol Microbiol 21: 321-329.

31. Miyamoto Y, Mukai T, Takeshita F, Nakata N, Maeda Y, et al. (2004) Aggregation of mycobacteria caused by disruption of fibronectinattachment protein-encoding gene. FEMS Microbiol Lett 236: 227-234.

32. Wiker HG, Harboe M (1992) The antigen 85 complex: a major secretion product of Mycobacterium tuberculosis. Microbiol Rev 56: 648-661.

33. Content J, Cuvellerie Adl, Wit LD, Vincent-Levy-Fre'bault V, Ooms J, et al. (1991) The genes coding for the antigen 85 complexes of Mycobacterium tuberculosis and Mycobacterium bovis BCG are members of a gene family: cloning, sequence determination, and genomic organization of the gene coding for antigen $85-\mathrm{C}$ of $\mathrm{M}$. tuberculosis. Infect Immun 59: 3205-3212.

34. Dheenadhayalan V, Shin KS, Chang CF, Chang CD, Wang SJ, et al. (2002) Cloning and characterization of the genes coding for antigen 85A, 85B and 85C of Mycobacterium avium subsp. paratuberculosis. DNA Seq 13: 287-294.

35. Camerom RM, Stevenson K, Inglis NF, Klausen J, Sharp JM (1994) Identification and characterization of a putative serine protease expressed 
Citation: Chaubey KK, Singh SV, Bhatia AK, Gupta RD, Gupta S, et al. (2018) Detection Limits of Recombinant Secretary Proteins versus Semipurified Protoplasmic Antigens for the Diagnosis of Spontaneous Cases of Mycobacterium avium subspecies paratuberculosis Infection in Domestic Ruminants. J Vet Sci Technol 9: 552. doi:10.4172/2157-7579.1000552

Page 9 of 9

in vivo by Mycobacterium avium subspecies paratuberculosis. Microbiol 140: $1977-1982$

36. Singh SV (1998) Diagnosis of paratuberculosis in goats. CSA University of Agriculture and Technology, Kanpur, India.

37. Singh SV, Singh AV, Singh PK, Sohal JS, Singh NP (2007) Evaluation of an indigenous ELISA for diagnosis of Johne's disease and its comparison with commercial kits. Indian J Microbiol 47: 251-258.

38. Singh AV, Singh SV, Singh PK, Sohal JS, Singh MK (2011) High prevalence of Mycobacterium avium subspecies paratuberculosis ('Indian bison type') in animal attendants suffering from gastrointestinal complaints who work with goat herds endemic for Johne's disease in India. Int J Infect Dis 15: 677-683.

39. Chaubey KK, Singh SV, Bhatia AK (2018) Evaluation of 'Recombinant secretary antigens' based 'Cocktail ELISA' for the diagnosis of Johne's disease and to differentiate non-infected, infected and vaccinated goats in combination with indigenous ELISA test. Small Ruminant Res 165: 24-29.

40. Sevilla IA, Singh SV, Garrido J, Aduriz G, Rodriguez S, et al. (2005) Molecular typing of Mycobacterium avium subspecies paratuberculosis strains from different hosts and regions. Revue Scientifique Et Technique 24: 1061 .

41. Chiodini RJ, van Kruiningen HJ, Merkal RS (1984) Ruminant paratuberculosis (Johne's disease): the current status and future prospects. Cornell Vet 74: 217-262.

42. Wadhwa A, Hickling GJ, Eda S (2012) Opportunities for improved serodiagnosis of human tuberculosis, bovine tuberculosis and paratuberculosis. Vet Med Int: 674238 .

43. Collins MT, Wells SJ, Petrini KR, Collins JE, Schultz RD, et al. (2005) Evaluation of five antibody detection tests for diagnosis of bovine paratuberculosis. Clin Diagn Lab Immunol 12: 685-692.

44. Pruvot M, Forde TL, Steele J, Kutz SJ, De Buck J, et al. (2013) The modification and evaluation of an ELISA test for the surveillance of Mycobacterium avium subsp. paratuberculosis infection in wild ruminants. BMC Vet Res 9: 5.

45. Gupta S, Singh SV, Bhatia AK (2017) Revisited immune reactivity between native semi-purified protoplasmic (caprine) versus commercial purified protoplasmic (bovine) antigens for the screening of goatherds endemic for Johne's disease. Indian J Biotechnol 16: 22-29.

46. Kumar A, Singh SV, Srivastava AK, Gangwar NK, Singh PK, et al. (2006) Comparative Evaluation of 'Indigenous' and Commercial Vaccines in Double Challenge Model for the control of Caprine paratuberculosis in India. J Biol Sci 14: 169-182.

47. Yadav D, Singh SV, Singh AV, Sevilla I, Juste RA (2008) Pathogenic 'Bison-type' Mycobacterium avium subspecies paratuberculosis genotype characterized from riverine buffalo (Bubalus bubalis) in North India. Comp Immunol, Microbiol and Infect Dis 31: 373-387.

48. Pahangchopi D, Singh RV, Singh SV, Das P ， Sharma D, et al. (2014) Evaluation of 'cattle' and 'Indian Bison' type antigens of Mycobacterium avium subspecies paratuberculosis for diagnosis of Bovine Johne's Disease using 'Indigenous ELISA' and AGPT. Indian J Exp Biol 52: 1182-1185.

49. Shisodiya AS, Panwar A, Singh SV, Singh PK, Singh AV, et al. (2009) Prevalence of mycobacterium avium subspecies paratuberculosis, An animal pathogen, in the population of animal keepers of Ghaziabad and Saharanpur districts of north India, using multiple diagnostic tests. Indian J Comp Microbiol, Immunol and Infect Dis 30: 42-44.

50. Andersen J, Lisby JG, Engbaek K, Ostergaard TO, Kornum LS, et al (1997) Mycobacterium paratuberculosis-an etiological agent in Crohn disease? Ugeskr Laeger 159: 159-163.

51. Bannantine JP, Stabel JR, Lamont EA, Briggs RE, Sreevatsan S (2011) Monoclonal antibodies bind a SNP-sensitive epitope that is present uniquely in Mycobacterium avium subspecies Para-tuberculosis. Front Microbiol 2: 1-13.

52. Malamo M, Sakoda Y, Ozaki H, Kida H (2006) Development of ELISA to detect antibodies specific to Mycobacterium avium subsp. paratuberculosis with truncated $34 \mathrm{kDa}$ proteins. Jpn J Vet Res 54: 99-107.

53. Shin SJ, Yoo HS, McDonough SP, Chang YF (2004) Comparative antibody response of five recombinant antigens in related to bacterial shedding levels and development of serological diagnosis based on $35 \mathrm{kDa}$ antigen for Mycobacterium avium subsp. paratuberculosis. J Vet Sci 5: 111-117.

54. Bannantine JP, Bayles DO, Waters WR, Palmer MV, Stabel JR, et al. (2008) Early antibody response against Mycobacterium avium subspecies Para-tuberculosis antigens in subclinical cattle. Proteome Science 6: 5 .

55. Samanich KM, Keen MA, Vissa VD, Harder JD, Spencer JS, et al. (2000) Sero-diagnostic potential of culture filtrate antigens of Mycobacterium tuberculosis. Clin Diagn Lab Immunol 7: 662-668.

56. Waters WR, Palmer MV, Thacker TC, Bannantine JP, Vordermeier HM, et al. (2006) Early antibody responses to experimental Mycobacterium bovis infection of cattle. Clin Vaccine Immunol 13: 648-654.

57. Shin SJ, Cho D, Collins MT (2008) Diagnosis of bovine paratuberculosis by a novel enzyme-linked immunosorbent assay based on early secreted antigens of Mycobacterium avium subsp. paratuberculosis. Clin Vaccine Immunol 15: 1277-1281.

58. Gumber S, Eamens G, Whittington RJ (2006) Evaluation of a pourquier ELISA kit in relation to agar gel immuno-diffusion (AGID) test for assessment of the humoral immune response in sheep and goats with and without Mycobacterium paratuberculosis infection. Vet Microbiol 115: 91-101.

59. Singh SV, Singh PK, Singh AV, Sohal JS, Sharma MC (2010) Therapeutic effects of a new "Indigenous Vaccine" developed using novel native "Indian Bison Type" genotype of Mycobacterium avium subspecies paratuberculosis for the control of clinical Johne's disease in naturally infected goat herds in India. Vet Med Int: 351846.

60. Willemsen PT, Westerveen J, Dinkla A, Bakker D, van Zijderveld FG, et al. (2006) Secreted antigens of Mycobacterium avium subspecies paratuberculosis as prominent immune targets. Vet Microbiol 114: 337-344.

61. Pradenas M, Jara MC, Hernandez N, Zambrano A, Collins MT, et al. (2009) Antibody recognition to secreted proteins of Mycobacterium avium subsp. paratuberculosis in sera from infected ruminants. J Vet Microbiol 138: 378-383. 